BOJANA PLEMIĆ

Academy of Applied Studies

Belgrade, Serbia

E-mail: bojana.plemic@visokaturisticka.edu.rs

LJUBIŠA VASILJEVIĆ

National Museum

Kruševac, Serbia

E-mail: ljubisa05@gmail.com
Received: September $13^{\text {th }} 2021$

Accepted: November $20^{\text {th }} 2021$

Original research article

904:255.6"652"(497.11)

255.6(398)

https://doi.org/10.18485/arhe_apn.2021.17.5

\title{
A CONTRIBUTION TO THE STUDY OF THE CULT OF THE GOD MITHRA IN MOESIA SUPERIOR: FINDINGS FROM THE MIDDLE AND SOUTHERN MORAVA VALLEY
}

\begin{abstract}
The paper presents the findings regarding the cult of Mithra from the territory of the Southern and Middle Morava River valley, which are taken into consideration according to their iconographic characteristics, as well as within the historical-geographical circumstances of the area to which they belonged during the Roman era. On the basis of the analysis of artistic details, it was concluded that these are monuments that mostly do not differ from the famous monuments of the cult of Mithra from our area, confirming the previously stated opinions of researchers that certain atypical iconographic traits on them probably arose as a result of insufficient understanding of the Mithraic doctrine, i.e. a lack of control in reproducing the canonised pattern of this cult. Furthermore, by considering the broader context of their findings, we also looked at possible ways in which the cult of Mithra could have been practiced in this area.
\end{abstract}

KEYWORDS: MITHRA, TAUROCTONY, ROMAN CULT, ICONOGRAPHY, THE SANCTUARIES, MORAVA RIVER VALLEY.

In the territory of the province of Moesia Superior, the cult of the god Mithra has been recorded in the form of a large number of findings (Зотовић 1973; Гавриловић-Витас 2017). In this paper, the immediate cause of which is the material from the exhibition "The cult of Mithra in the environment of the confluence of the three Morava rivers" of the National Museum Kruševac, from 2011 (Рашковић 2011), our intention is to contribute to a better understanding of the nature of this cult in Roman provinces by considering the iconographic characteristics and the broader context of their findings. These findings are votive reliefs that were recorded in Ćuprija, the village of Dragovo near
Rekovac and in the area of the village of Džigolj near Prokuplje, then the village of Nozrina near Aleksinac and the surroundings of the village of Ražanj, i.e. from sites that mostly follow the main road between two large urban settlements of the Roman era, the municipality of Horreum Margi and the peripheral area of Naissus (Map 1).

\section{THE MORAVA RIVER VALLEY DURING THE ROMAN ERA}

From a geographical point of view, the territory whence the mentioned findings come from 


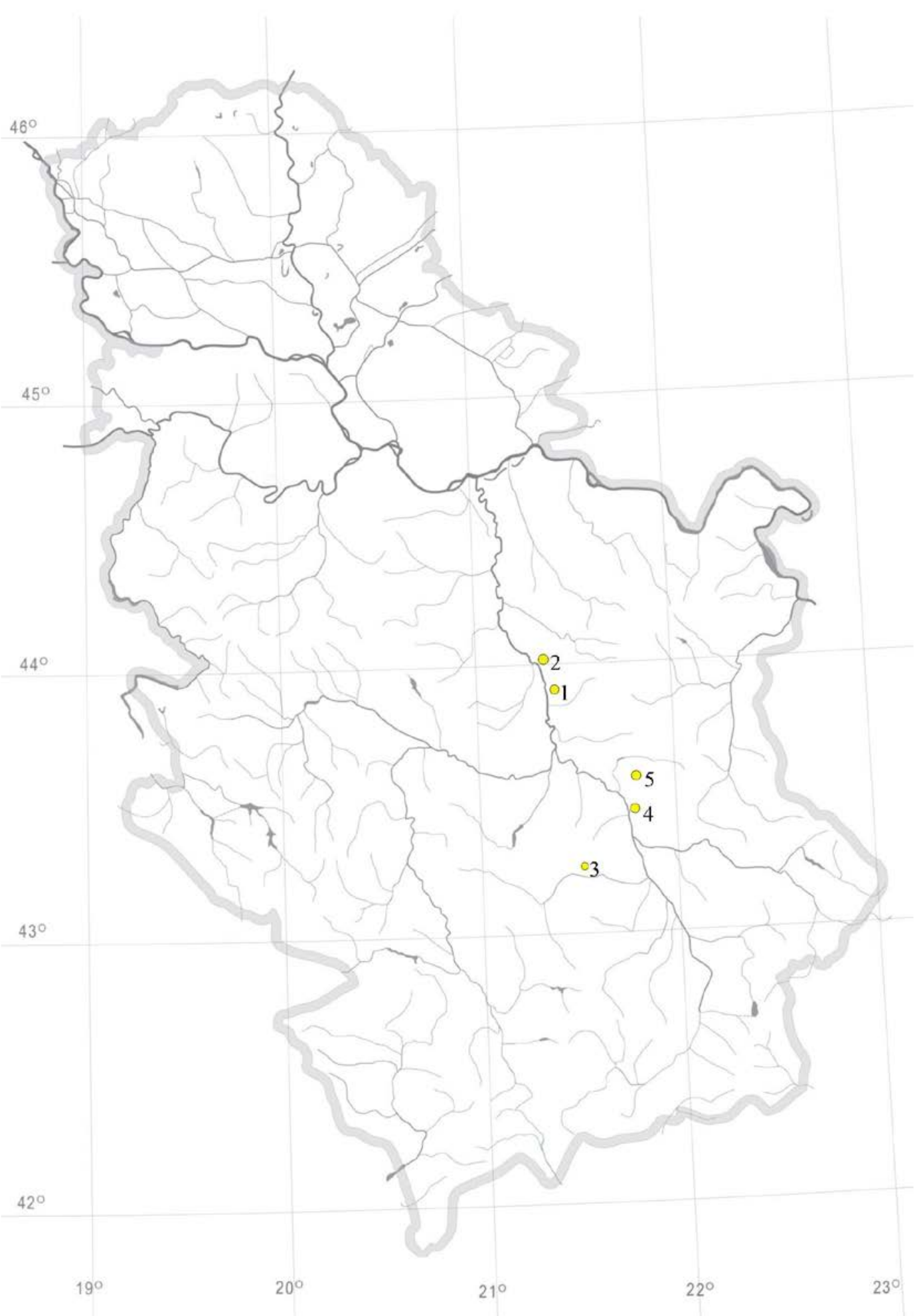

Map 1 Sites of the cult of Mithra of the Southern and Middle Morava River valley (author: Nataša Miladinović). 
includes the area of the Middle Morava River valley and the northern part of the Southern Morava River valley, i.e. the valley of Aleksinac. Today, the Middle Morava valley completely coincides with the territory of the Pomoravlje administrative district, which consists of five municipalities - Paraćin, Ćuprija, Despotovac, Svilajnac, Rekovac and the city of Jagodina, extending over the territory of the conurbation of Jagodina-Ćuprija-Paraćin (Танић 2016: 9-10). The position of the Middle Morava valley clearly indicates the great strategic importance of this area, which was recognised during Antiquity as well, since it is located in the northern part of the Morava-Vardar valley, as the main natural road and the main connecting line between the Aegean Sea and the Middle Danube Valley, or the interior of the Balkans and Pannonia. On the opposite side, the valley of Aleksinac, encompassing the northern part of the flow of the Južna Morava River, is bordered by the mountains of Poslonske Planine and Bukovik in the north, Bovan gorge and Ozren in the east, the hills of Mojsinje and Mali Jastrebac in the west, and the valley of Niš in the south, continuing the above mentioned communication towards Northern Macedonia. (Рашковић 2006: 205).

It is believed that the Romans were present in the Morava River valley from the second half of the $2^{\text {nd }}$ century $\mathrm{BC}$, when they set out on expeditions to the territories north of the province of Macedonia, while during the $1^{\text {st }}$ century BC, Roman legions sought to establish their positions within the Balkan Peninsula and on the Danube, with this territory playing an important role (Mirković 1996: 29). Finally, it became part of the Roman state around the year 15 , when the areas of the Dardanians, Tribals and Moesi became part of the province of Moesia. Realising the strategic importance of this area, the Romans soon started the construction of the road (Via millitaris), which was completed in the year 33, connecting the interior of the Balkans with the Danube Valley and enabling the transfer of the Roman army from Greece and Thrace to Pannonia. This im- portant communication started from Singidunum, through Viminacium across the Morava Valley, where there were numerous settlements and road stations on the way to Naissus and Constantinople (Петровић 2007: 68-74; Рашковић 2017a).

In addition to its role in terms of traffic, the Romans realised the logistical importance of the Morava Valley, so this area had a significant role later as a granary that fed not only the army in the Danubian limes, but also the neighbouring mining areas (Рашковић 2006: 210-220). Thus, a settlement with the military fortification of Horreum Margi (Ćuprija) stands out in this area as the main station for collecting food products, primarily cereals, in the valley of the river Margus (Velika Morava), while its importance is also evidenced by the fact that it was an episcopal see in the $4^{\text {th }}$ century. Horreum Margi was founded at the beginning of the $2^{\text {nd }}$ century, and during the $3^{\text {rd }}$ century it was surrounded by ramparts, and then additionally extended to the west at the beginning of the $4^{\text {th }}$ century (Tapavički-Ilić and Petković 2017: 165-166). The first destruction of the fortification occurred during the $3^{\text {rd }}$ century, with the invasion of the Goths in the territory of the Balkan Peninsula, and the peak of instability of the Roman administration occurred after the battle of Hadrianopolis in 378. However, life in this Roman settlement died out only after the Huns invasion in the period 441-443, as was essentially the case with most others in the Morava Valley (Васић и Петковић 2010: 21-22).

In the territory to which the mentioned findings of the cult of Mithra belong, two road stations have been located with certainty, mansio Idimum and mansio Praesidium Pompei, known from late antique road maps such as Tabula Peutengeriana, then Itinerarium Antonini Augusti and Itinerarium Hierosalymitanum (Itinerarium Burdigalense) (Vasić and Milošević 2000: 9; Рашковић 2006: 213; 2017a: 67-69). Thus, Mansio Idimum was located near the village of Medveđa, on the left bank of the Resava river, representing a post and road station on the public road Viminacium-Nais- 
sus, about 16 miles from Horreum Margi (Vasić and Milošević 2000: 9). The Praesidium Pompei station was located at the site of Zindan in the village of Ćićina, on a vast fertile terrace, through which the public road passed, following the course of the river. It was an open-type mansio that existed from the second half of the $3^{\text {rd }}$ century, with a fortification added at the beginning of the $4^{\text {th }}$ century. Thanks to the material remains and mobile findings from that site, it is known that the settlement was located next to the mansio, as the seat of the civil administration and, according to the epigraphic testimonies, the military unit of the II cohort of the Dardanians (cohors II Aurelia Dardanorum) resided here, which was formed by Emperor Marcus Aurelius for the purpose of fortifying the border of the territory of Naissus in the north during the Marcomannic wars (Ђорђевић и Рашковић 2004: 33-34, 36).

Late antique itineraries record the presence of other stations and settlements along the route of the public road Horreum Margi - Naissus, such as mutatio Sarmatorum, Praesidium Dasmini, mutatio Cametas and mutatio Rappiana as stops alongside roads that merged with the main road communication (Рашковић 2017a: 60). According to numerous archaeological findings from the Roman period in the areas of the villages on the left bank of the Južna Morava, it is believed that the main road from Praesidium Pompei to Naissus led right there (Гарашанин и Гарашанин 1951: 45-46, 166-169). When it comes to the monuments of the cult of Mithra that will be discussed here, it is important to note that mutatio Cametas was usually placed in the village of Ražanj near Aleksinac in older literature, where a late antique necropolis was found at the site of Nišbar in 1954 (Јуришић 1956; Зотовић-Жунковић и Шалабалић 1958-1959: 205), while according to a more recent opinion, this necropolis can only be considered a part of Cametas, and the Roman settlement and the road station were most likely located in the immediate vicinity, in the area where the villages of Kačanica and Lipovac meet (Рашковић 2017a:
67). Also, an assumption was made that mutatio Rappiana could have been located in the village of Nozrina, as indicated by a large concentration of findings, as well as its distance of 12 Roman miles in relation to the station Praesidium Pompei, which corresponds to its location on late antique maps (Рашковић 2017a: 71).

The importance of this area during the Roman era, in addition to testimonies that speak in favour of the existence of road stations and settlements, is emphasised by findings of a religious nature, indicating the peculiarities of the sacral practice. However, it is necessary to point out that a major problem here is the insufficient level of research, because in this region, except in the case of the site of Horreum Margi, the small amount of data that we have at our disposal has been obtained through systematic archaeological research. This fact has been repeatedly pointed out in literature, and, accordingly, the placing of the mentioned settlements is based mainly on data from literary sources, i.e. material obtained by field surveys or through gifts from private individuals (Кузмановић-Цветковић 1995: 169; Рашковић 2013; 2017: 71-72).

\section{CATALOGUE}

Marble relief from Ćuprija (Horreum Margi Ravno Museum, inv. no. 614) - Fig. 1.

Dimensions: height $35 \mathrm{~cm}$, width $57 \mathrm{~cm}$, thickness 9-10 cm.

References: Васић и Петковић 2010: 17, fig. 7; Васић 1992; Tapavički and Petković 2017: 165166, fig. 1.

Fragment of a relief depicting the god Mithra in the act of tauroctony, with the torchbearers Cautes and Cautopates, next to him. The rest of the decorated outlet that frames the scene can be seen on the left side of the relief. In front of the body of a prostrate bull, the figure of a snake with its head raised towards a wound on the bull can be seen, while on its right side there is a figure of a dog. 


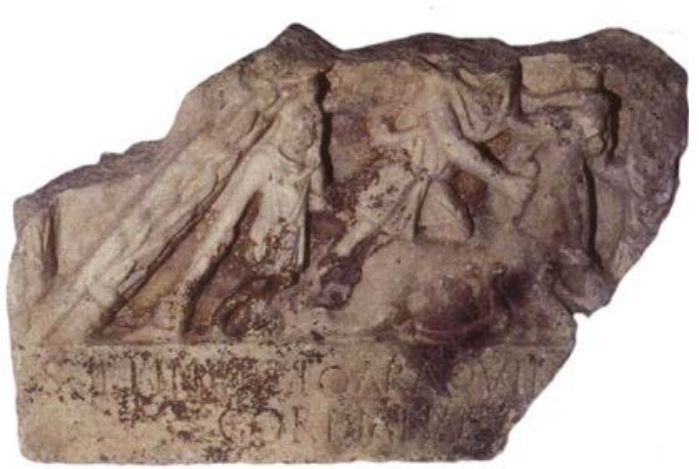

Fig. 1 Marble relief with the representation of the Mithras from Ćuprija (after:Tapavički and Petković 2017: fig. 1).

Below the central field with the figural representation there is an inscription which is reconstructed as: SOLI INVICTO AVR(elius) AQUIL[a \pm 12 letters] GORDIANAE V(otum) [s(olvit) l(ibens) $m($ erito)].

Marble relief, village of Dragovo (Regional Museum Jagodina, inv. no. 47_5.) - Fig. 2. ${ }^{1}$

Dimensions: height $14 \mathrm{~cm}$, width $12 \mathrm{~cm}$, thickness $1 \mathrm{~cm}$.

References: Vetnić 1967: 117; Зотовић 1973: 25; Cvetković i Dodić 2001: 60, sl. 29.

Fragmentarily preserved relief with a central representation of the god Mithra in the act of tauroctony, with torchbearers next to him. Cautes and Cautopates are holding a pedum instead of torches. In front of the prostrate body of a bull, there is a snake with its head raised in the direction of a wound on the bull's neck, while on the lower part of the relief there is a frieze with three scenes illustrating the

1 On this occasion, we would like to cordially thank our colleague Smiljana Dodić from the Regional Museum Jagodina for the photo of the finding.

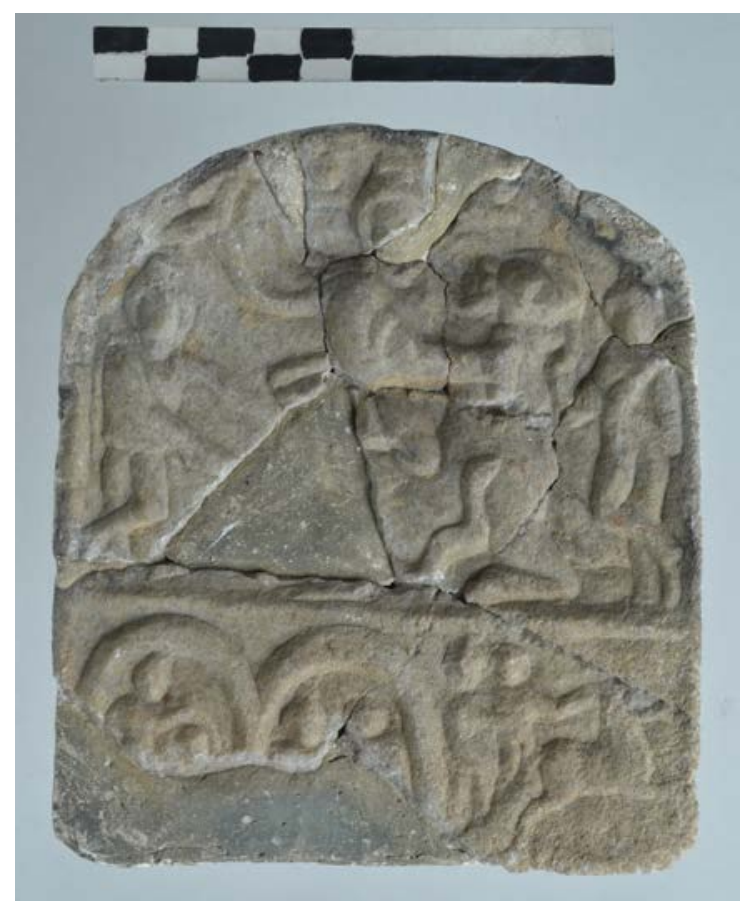

Fig. 2 Marble relief with the representation of the Mithras from the village of Dragovo (photo: Zavičajni muzej Jagodina).

rite of initiation into the cult and scenes related to the mythological cycle of Mithra and Sol.

Marble relief, village of Džigolj (National Museum of Toplica inv. no. 900) - Fig. 3.

Dimensions: height $28 \mathrm{~cm}$, width $28.5 \mathrm{~cm}$, thickness $3.5 \mathrm{~cm}$.

References: Кузмановић-Цветковић 1995.

Relief with a representation of the god Mithra in

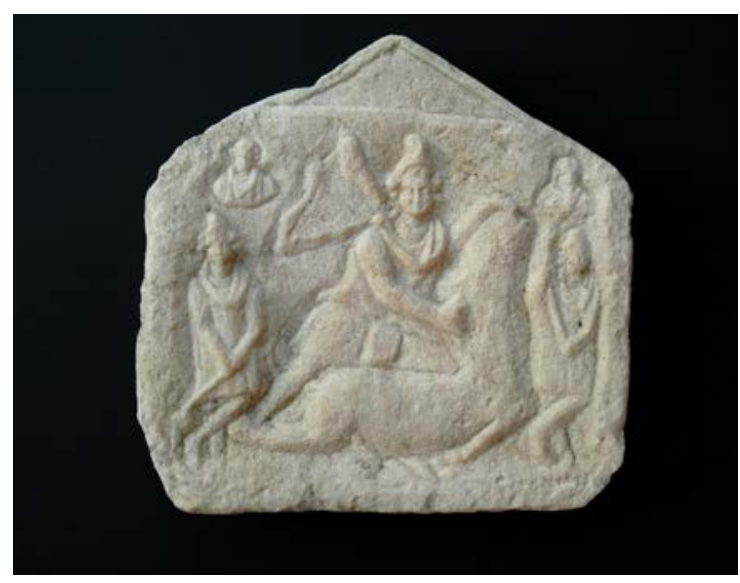

Fig. 3 Marble relief with the representation of the Mithras from the village of Džigolj (photo: Petar Ćeranić). 
the act of tauroctony, with torchbearers next to him. Above them are the busts of Sol and Luna, while the figure of a raven is given on the edge of the chlamys of the god Mithra. Above that image, in a rectangular field, there is a gable with no decoration.

Marble relief, village of Nozrina (National Museum Kruševac, inv. no. 4) - Fig. 4.

Dimensions: height $17.7 \mathrm{~cm}$, width $23.4 \mathrm{~cm}$, thickness $3.5 \mathrm{~cm}$.

References: Рашковић 2013: 76, сл. 1; Васиљевић 2017: 24.

A fragment of a relief composed of four parts, on which the lower part of a representation of the god Mithra in the act of tauroctony can be identified, with torchbearers, Cautes and Cautopates, next to him. In front of the body of a prostrate bull, the figure of a snake with its head raised towards a wound on the bull can be seen, while the figure of a dog can be noted on its right side. There is a relief frieze in the lower part with four separated representations, which provide a standard depiction of the rite of initiation into the cult and scenes related to the mythological cycle of Mithra and Sol, while the first scene consists of a figure riding an animal (bull or horse?).

Marble relief, area of Ražanj (National Museum in Niš, inv. no. 1095) - Fig. 5. ${ }^{2}$

Dimensions: height $32 \mathrm{~cm}$, width $33 \mathrm{~cm}$, thickness $1.5 \mathrm{~cm}$.

References: Зотовић-Жунковић и Шалабалић 1958-1959; Зотовић 1973: 61-62; Petrović 1979: 113-114, n. 93; Пешић 2004: 165, кат. 88; Рашковић 2013: 59, Т. І, 1; Гавриловић-Витас 2017: сл. 1-2;

Marble relief with a central representation of the god Mithra in the act of tauroctony, with torchbearers, Cautes and Cautopates, next to him. There is a bust of the goddess Luna above Cautes,

2 We would like to cordially thank our colleague Vesna Crnoglavac from the National Museum in Niš for the photo of the finding.

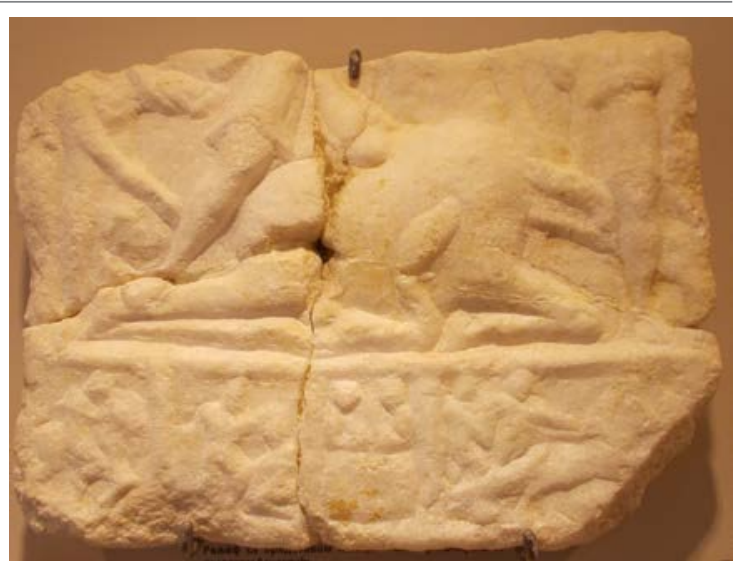

Fig. 4 Marble relief with the representation of the Mithras from the village of Nozrina (photo: Narodni muzej Kruševac).

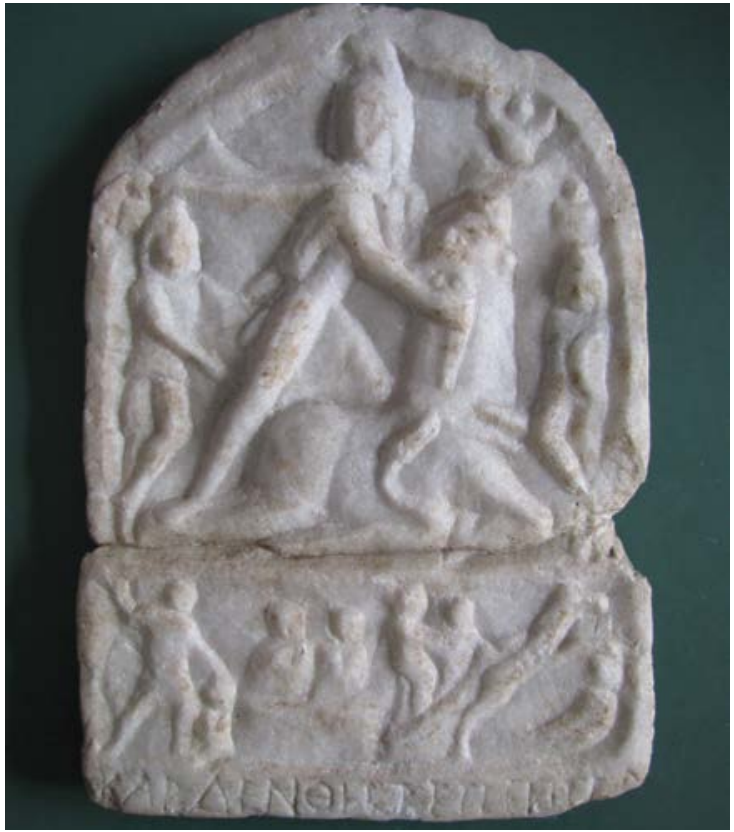

Fig. 5 Marble relief with the representation of the Mithras from the area of Ražanj (photo: Narodni muzej Niš).

while a very summary scene of Mithra's birth is given above Cautopates. Below the bull, there is the figure of a snake with its head raised towards a wound on the bull, depicted in full length. A relief frieze is at the bottom, with three scenes illustrating the rite of initiation into the cult and scenes related to the mythological cycle of Mithra and Sol. There is a short inscription in ancient Greek beneath it, which is partly illegible. The dedicant

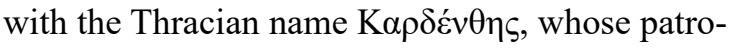

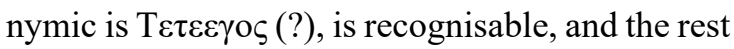
is most likely an abbreviated votive formula. 
ICONOGRAPHIC TRAITS OF THE FINDINGS

The findings of the cult of Mithra that we present in this paper can be divided into two groups: those that have only a central field with a tauroctony and those with a lower frieze with scenes as well. The first group includes findings from Ćuprija and Džigolj (Figs. 1, 3), and the second from the villages of Dragovo, Nozrina and the surroundings of Ražanj (Fig. 2, 4, 5). ${ }^{3}$ The scene of tauroctony, as the main depiction of the Mithraic cult, ${ }^{4}$ is given on all the mentioned reliefs in the standard manner: the god Mithra, dressed in a fluttering chlamys, presses down a bull with one foot, standing on the ground with the other, and stabs him with a dagger at neck height. In addition to the deity, in all cases, the classic depictions of dadophoroi, Cautes and Cautopates, are given, in a standing position with crossed legs, frontally or in half profile. They are holding torches pointed in different directions, and it is only on one finding from Dragovo that one of them holds a pedum, as a typical detail of the iconography of Mithraic reliefs from Moesia Superior (Vetnić 1967: 117; Зотовић 1973: 25,

3 According to the typology of L. A. Campbell, all Mithraic reliefs are divided into eight groups (I-VIII), with subtypes marked with letters from A to E (Campbell 1968: 1-3). Accordingly, the reliefs from Ćuprija and Džigolj belong to the first type, while the examples from the village of Dragovo and the surroundings of Ražanj belong to the second and seventh group, where types whose field ends in a semicircle and with a lower three-part frieze are classified. When it comes to the relief from Nozrina, it is not possible to determine the exact typological affiliation because there is no preserved upper part, while there are four scenes on the lower frieze. Additionally, all the icons we consider in this paper belong to subtype A, which includes representations of a tauroctony where the god Mithra is depicted frontally, with a bent left leg placed on the back of a slightly smaller figure of a bull.

4 The representation of the god Mithra in the act of tauroctony, the symbolic killing of a bull, is considered a cosmogonic act of a deity who thus saves the world from ruin. Today, most researchers have accepted that the scene of tauroctony is a star map on which each figure symbolises a certain constellation, and other artistic contents on the cult objects of the god Mithra are interpreted accordingly (Gordon 1975: 215-248; Hinnells 1975; Beck 1976: 95-98; 1988; Ulansey 1991).
131). Beneath the prostrate bull is a representation of a snake on all findings except for the one from Džigolj, while the standard figure of a dog attacking the bull on the right can be recognised in the reliefs from Ćuprija and Nozrina. Additionally, the relief from the village of Džigolj shows a raven, almost on the edge of the fluttering dress of the deity, with the busts of Sol and Luna depicted above, and on the example from the area of Ražanj, it seems that only Luna's bust is represented.

The lower frieze with scenes below the tauroctony appears on reliefs from the villages of Dragovo, Nozrina and the surroundings of Ražanj. These are representations that continually fill the lower part of these plates, standardly illustrating the rite of initiation into the cult, ${ }^{5}$ the sacred feast of Mithra and Sol, and the departure of the deities, in Sol's chariots, to heaven, that is, to immortality. This type of icon is associated with the so-called Danubian provinces of the Roman Empire, and it is believed that its iconography was probably formed in the bordering area of Moesia Superior and Moesia Inferior, from where it spread to the territory of the mentioned provinces, starting from the second half of the $2^{\text {nd }}$ century (Najdenova 1989: 1417-1419; Гавриловић-Витас 2017: 200-201). In the area of Moesia Superior, the appearance of such icons has been confirmed many times, so we find close analogies for them on examples from nearby Mramor, near Niš (Гавриловић-Витас 2017: fig. 3-4), the village of Ragodeš, near Pirot, and Belgrade (Vermaseren 1960: fig. 619, mon. 2243; Зотовић 1973: 15, fig. 1, 60-61; Гавриловић-Витас 2017: 200, fig. 7-8).

The literature traditionally emphasises the peculiarity of the iconography of the Danube re-

5 It is a scene where one standing figure swings his hand or places it on the head or shoulders of another kneeling figure, which used to be interpreted, in older literature, as the end of the massive battle of Mithra and Sol, i.e. the act in which Sol expresses his final submission to Mithra, which was considered typical for the reliefs from the area of the Balkans (Cumont 1903; Vermaseren 1960: 80). However, L. A. Campbell's explanation is generally accepted today, who identifies the rite of initiation into the cult in that scene, taking place in the mithraeum (Campbell 1968: 291). 
liefs, as well as their consistency (Hinnells 1975: 52; Turcan 1996: 213), while more recently the emphasis has been on the artistic specificities of the monuments of the Mithraic cult from the Roman provinces of the Central Balkans, conditioned by the geographical, temporal and social context (Гавриловић-Витас 2017: 202). It is in this context that we can view the details of reliefs discussed here: thus, on the example from Cuprija, we can see the rest of a decorated frame with floral ornaments around the scene of tauroctony, which is assumed to have had the shape of a trapezoid or triangle, something not known from other Mithraic monuments (Tapavički-Ilić and Petković 2017: 166). Two explanations are offered for this detail: according to one hypothesis, the craftsman who made this relief did not really understand the symbolism of the depicted scene and thus placed it in an imaginary environment, rather than in the symbolic representation of a cave, while according to the other, the emphasis is on the symbolism of the triangle as a heavenly roof and a place where the plane of the gods meets that of the mortals (Васић 1992: 382). We are more inclined to favour the first hypothesis, that is, the possibility that this was in fact an inconsistent imitation of the framed scene of tauroctony known from some Italian examples. We will mention the relief with Mithra that is built into the renaissance Palazzo Mattei in Rome today, on which a similarly made ornamental arch-shaped outlet can be seen, which resembles the flat shape of a triangle in the lower left part, as can also be seen on one of reliefs with Mithra from the Vatican Museum (Vermaseren 1960: mon. 534, 546-547). What is typical for both those scenes from the territory of Italy is that only a figure of a deity with a wounded bull is placed in a frame, while Cautes and Cautopates are either not represented or placed outside of it. This reinforces the impression of a poorer compositional solution of the relief from Ćuprija even further, where the dadophoroi are disproportionately incorporated within the profiled field.

Furthermore, the empty gable field that ap- pears at the top of the icon with Mithra from Džigolj was mostly uncommon on reliefs of this cult (Vermaseren 1960: fig. 500, mon. 1919). Otherwise, the very shape of this icon - a rectangle with a gable - is somewhat rarer in the Central Balkans, where only few more such examples have been recorded (Зотовић 1973: cat. 30, 37, $47 \mathrm{e}, 106)$. Also, there are no main cult animals on this relief - namely, snake and dog, while a raven and possibly a scorpion are represented, which can only be guessed at due to the poor execution (Кузмановић-Цветковић 1995: 166). This icon is made of coarse grain marble from the vicinity of Prokuplje, which suggests that it was made by a local craftsperson who could have known the artistic pattern of representations of Mithra, but was not able to implement it consistently.

A provincial character of production is also attributed to the icon from the area of Ražanj, which is a mediocre work with unskilfully executed details. This is evidenced by the figure of Cautes, who was pushed aside along the left edge, which caused a lack of space for his figure, which was, therefore, executed in a very simplified manner (Зотовић 1973: 61; Гавриловић-Витас 2017: 200). The scene of Mithra's birth from a rock is shown in a similar manner (Mithras petragenes), almost continuing above the head of Cautes. Mithra is depicted naked, with a Phrygian cap on his head, a knife in one hand and a torch in the other, as symbols that indicate that the god born from a rock was the creator of light and all life on earth. It is one of the scenes from the cycle of Mithra, which is represented in the friezes around the tauroctony scene, but is more typical of reliefs from the western provinces (Гавриловић-Витас 2017: 197, нап. 27).

Lastly, on a Mithraic icon from the village of Nozrina, on the lower frieze, instead of the standard three, there are four scenes. In addition to the scenes that usually represent the rite of initiation into the cult, the sacred feast of Sol and Mithra and the ascension of the deities in Sol's chariots to heaven, the first scene, that of a figure riding 
an animal, stands out here. Mithraic icons typically feature a scene where this deity rides a bull or is shown almost lying on it while it is prancing or racing, wrapping his arms around its neck or holding it by the horns, often as part of smaller scenes arranged around the main scene of tauroctony. However, in accordance with the artistic traits of this representation, where one can see a bent rider on an animal in fast trot, one should not rule out a slightly smaller possibility that it is Mithra on horseback. In that case, it would be a rather rare depiction, especially on the lower frieze of Mithraic icons, while such an iconographic setting is recorded in larger numbers only in the so-called German monuments (Vermaseren 19561960: 1083, 1137, 1247a, 1289, 1292), where an interconnection of such scenes, as an allusion to hunting, with depictions of the sacred feast, was observed (Dirven 2016: 20).

In terms of the style, we can say that almost all the Mithraic reliefs we are discussing here were made in a very simplified manner, with schematically executed scenes and poorer general compositions. In addition to the iconographic deviations that we have pointed out, this speaks in favour of their provincial provenance, i.e. the possibility that in some cases, due to the insufficient knowledge or understanding of the Mithraic doctrine itself and its artistic expression, there was a lack of control in reproducing the canonised pattern of this cult (Зотовић 1973: 111-112; КузмановићЦветковић 1995: 168).

\section{THE FINDING CONTEXT OF MITHRAIC RELIEFS IN THE MIDDLE AND SOUTHERN MORAVA VALLEY}

Considering the fact that only examples from Ćuprija and Dragovo were excavated during systematic archaeological excavations, we have somewhat more detailed data on the context of those findings. The icon of Mithra from Cuprija was found during excavations in 1990 in the area of a military fortification, when the stratigraphy of cultural layers along its northern and eastern ramparts was investigated. The dedication on this monument is in accordance with the finding place - by Aurelius Aquila, soldier of Legio IV Flavia or Cohors II Aurelia Dardanorum, which is why it was dated into the fourth or fifth decade of the $3^{\text {rd }}$ century (Васић 1992: 384-385; Tapavički-Ilić and Petković 2017: 165). On the other hand, the relief from the village of Dragovo is testimony to the existence of a place located next to a forest spring where the cult of Mithra was practiced. Namely, this small icon was secured with iron wedges to the side of a large, crude stone block, which probably formed the altar of the sanctuary, while a hearth was located in its vicinity, with several plates on which sacrifices were offered. Next to the altar, a hoard of money was found, as well as pottery fragments, while several remains of burnt animal bones and pottery were recorded in the hearth itself. The findings from the area of this sanctuary include one fibula, as well as several fragmented vessels decorated with a relief depiction of snakes (Vetnić 1967; Cvetković and Dodić 2001: 60).

The icon of Mithra from Džigolj, from the slopes of Mali Jastrebac, was an accidental finding from when a well was being dug on a private property. A few more stones were removed from the same place, indicating the possibility that there was once a building there, but the layered deposits of mud brought by a nearby stream make it impossible to find additional traces that would confirm what it really was (Цветковић-Кузмановић 1995: 168-169). Although no significant remains of Roman culture have been recorded in Džigolj itself, remains of several late antique villas and buildings, such as thermae and built tombs, were found only a few kilometres away (ЦветковићКузмановић 1995: 165), which nevertheless point to the possibility that the inhabitants of that estate could have practiced their religious rites in a sacred place near a forest spring, analogous to the one from the village of Dragovo. 
As for the relief from the village of Nozrina, also an accidental finding, by considering data from the literature and other archaeological material found in the same place, it can be concluded that it could have been a votive gift from a smaller temple where other deities were worshiped. Namely, in the village of Nozrina, on the site of Mogile, from where an icon with Mithra came, two stone sarcophagi, a luxurious bronze vessel, a bronze head, ceramics and a silver coin of Marcus Aurelius were found in a tumulus, in the 19th century (Рашковић 2013: 63), and somewhat later, a fragmented tombstone, stone statuettes of lions, architectural remains and a tomb built with bricks were also discovered (Вулић 1934: 49; Јовановић 1980: 5; Рашковић 2013: $63)$. The fact that fragments of marble reliefs depicting Sol-Apollo and the Thracian horsemen came from there is also of great importance to us, as well as the fragments of a marble icon of Jupiter and a small part of a cult image of Jupiter and Juno, today in private ownership (Рашковић 2013: 64, Т. 4-5; Васиљевић 2017: 23-25). It is precisely the number of votive monuments from the site of Mogile, along with the concentration of other findings from the Roman era, that is the basis for the already mentioned assumption that the village of Nozrina was once a road station of mutatio Rappiana (Рашковић 2017a: 71), i.e. that it could have been a developed Roman settlement with a smaller sanctuary.

Finally, in the case of the icon with Mithra from the surroundings of Ražanj, it was considered that it originated from Ražanj itself because it was brought from its Cultural Centre to the National Museum in Niš (Гавриловић-Витас 2017: 188, нап. 1). This possibility was also indicated to the researchers by the remains of the walls of an ancient building and necropoles from the 4th century in Ražanj (Зотовић-Жунковић и Шалабалић 1958-1959: 205). However, according to more recent field data, the locals found this icon not far from Ražanj, on a stretch of land called Drugovac, between the villages of Rujište and Crni Kao, which stands out in the wider vicinity of the valley of Aleksinac because of the richness of accidental findings and number of layers, while the station mutatio Cametas could have been in its immediate vicinity (Рашковић 2013: 59; 2017a: 72).

\section{CONCLUDING REMARKS}

From all that we have discussed above, it can be seen that the territory we have considered on this occasion is very rich in material from the Roman and Late Antiquity era, however, obtaining a better overview of it would certainly require a more thorough exploration of this terrain. Despite such a situation, its religious complexity is obvious, even from the modest data we have presented here. Although only few classical mithraea were recorded on the territory of Moesia Superior, and it is believed that, due to the historical development of this province and the instability of its borders, the cult of Mithra was practiced only within smaller temporary chapels (Зотовић 1973: 12), we have hinted here at some other possible ways it could have been practiced. Namely, regardless of the fact that the small quantity of findings from the village of Dragovo, as well as the central arae found near the forest spring on the same site, does not allow for a more precise determination of this sanctuary or the assumption of an open spelaeum (Зотовић 1973: 25), the parallel with the finding from Džigolj, which also originates from terrain near a forest stream, indicates that the cult of Mithra could have been practiced in the open air, i.e. in hidden forest sanctuaries by water. Additionally, in terms of more urban areas, this deity was most likely worshiped along with other solar deities such as Apollo and the Thracian horsemen, ${ }^{6}$ and such a collective finding was recorded

6 Mithra, Helios/Apollo and the Thracian horsemen are somewhat related deities because of their solar character, which was especially emphasised during the second half of the $3^{\text {rd }}$ century. It was then, under the strong oriental influence of combining religion with astrology and philosophical tendencies, that the Roman religion was directed 
not only in the village of Nozrina, but also in the Morava River valley under the hill of Karađorđevo Brdo, near Paraćin (Cermanović-Kuzmanović 1963: 32-33). When it comes to the repertoire of worshiped deities, a similar parallel can be seen at the site of Sveta Trojica (Holy Trinity) in Ravna (Timacum Minus), where, in addition to the monuments of Apollo (or Asclepius) and the Thracian horsemen, a significant number of reliefs of Jupiter and Juno were registered (Jovanović 2007: 176-183). As the dyad of Jupiter and Juno is marked with the phrase "Thracian Zeus and Hera" due to the frequency of votive tablets with their representation in the central and western part of Thrace, in the regions of Philippopolis, Serdica and Pautalia (Јовановић 2007: 180, 183; Вълчев 2015: 118-121, карта 5), the mentioned site in Ravna is also brought into connection with the sacral ambience intended for the population of Thracian origin. That is additionally witnessed by the dedications of soldiers from the cohort II Aurelia Dardanorum, which was stationed in Ravna (Petrović 1995: 70-71, 92-93, no. 13, 44). We believe that a similar influence could have existed in the area of the Morava Valley, as confirmed by the votive inscriptions of dedicants with Thracian names on the relief with Sol-Apollo from the village of Nozrina or on the relief with Mithra from the surroundings of Ražanj (Зотовић-Жунковић и Шалабалић 1958-1959: 209; Зотовић 1973: 62; Petrović 1979: 114; Veljković and Vasiljević 2020). Therefore, we hope that any new findings of the cult of Mithra from this area will possibly further clarify the manner in which this cult was practiced, which is certainly a task worthy of future research attention.

towards monotheism, and cults of deities such as Jupiter, Mars, Serapis, Dionysus or Mithra became only local manifestations of one or the supreme god Helios i.e. Sol (Пилиповић 2011: 78-79). Additionally, the cult community of the Thracian horsemen and Apollo is known from the wider Thracian areas, where these gods intertwined because of their solar nature and iatric function, especially through monuments with the standard iconography of the Thracian horsemen with a dedication to Apollo (Dimitrova 2002: 216).

\section{BIBLIOGRAPHY}

\section{Beck, R. 1976}

The seat of Mithras at the equinoxes: Porphyry, De Antro Nympharum 24, Electronic Journal of Mithraic Studies 1/1: 95-98.

\section{Beck, R. 1988}

Planetary gods and planetary orders in the mysteries of Mithras, Leiden: Brill.

\section{Campbell, L. A. 1968}

Mithraic Iconography and Ideology, Leiden: Brill.

\section{Cermanović-Kuzmanović, A. 1963}

Die denkmaler des trakischen Heros in Jugoslawien und das Problem des trakischen reitergottes, Archeologica Iugoslavica 4: 32-39.

\section{Cumont, F. 1903.}

The Mysteries of Mithras, Chicago: Open court.

Cvetković, B. i Dodić, S. (ur.) 2001

Zavičajni muzej Jagodina, Stalna izložbena postavka - Katalog, Jagodina: Zavičajni muzej.

\section{Dimitrova, N. 2002}

Inscriptions and Iconography in the Monuments of the Thracian Rider, Hesperia 71/2: 209-229.

\section{Dirven, L. 2016}

A New Interpretation of the Mounted Hunters in the Mithraeum of Dura-Europos, in: Icon, Cult, and Context. Sacred Spaces and Objects in the Classical World, eds. M.K. Heyn and A. Irvine Steinsapir, Cotsen: Institute of Archaeology, 17-33.

\section{Ђорђевић, М., Рашковић, Д. 2004}

Налазишта и налази римског периода на доњем току Јужне Мораве, Саопштења XXXVXXXVI (2003-2004): 29-56.

(Đorđević, M. i Rašković, D. 2004

Nalazišta i nalazi rimskog perioda na donjem 
toku Južne Morave, Saopštenja XXXV-XXXVI (2003-2004): 29-56).

\section{Гавриловић-Витас, Н. 2017}

Вотивне иконе бога Митре из Античке збирке Народног музеја у Нишу, Зборник радова Народног музеја - Археологија XXIII: 187-206. (Gavrilović-Vitas, N. 2017

Votivne ikone boga Mitre iz Antičke zbirke Narodnog muzeja u Nišu, Zbornik Narodnog muzeja-Arheologija XXIII: 187-206).

Гарашанин, М., Гарашанин, Д. 1951

Археолошка налазишта у Србији, Београд: Просвета.

(Garašanin, M. . Garašanin, D. 1951

Arheološka nalazišta u Srbiji, Beograd: Prosveta).

\section{Gordon, R. 1975}

Franz Cumont and the doctrines of Mithraism, in: Mithraic studies, Proceedings of the First International Congress of Mithraic Studies II, ed. J. R. Hinnells, Manchester: Rowman and Littlefield, 215-248.

\section{Hinnells, J. R. 1975}

Reflections on the bull-slaying scene, in Mithraic studies, Proceedings of the First International Congress of Mithraic Studies II, (ed.) J. R. Hinnells, Manchester: Rowman and Littlefield, 290-312.

\section{Јовановић, А. 1980}

Тумули из античког периода у југоисточној Србији и на Косову, Старинар XX: 1-16.

(Jovanović, A. 1980

Tumuli iz antičkog perioda u jugoistočnoj Srbiji i na Kosovu, Starinar XX: 1-16).

Јовановић, А. 2007

Огледи из античког култа и иконографије, Београд: Филозофски факултет

(Jovanović, A. 2007

Ogledi iz antičkog kulta i ikonografije, Beograd: Filozofski fakultet).

\section{Јуришић, А. 1956}

Ражањ-Нишбар, Саопштења Завода за заштиту споменика културе Народне Републике Србије I: 133-135.

(Jurišić, A. 1956

Ražanj-Nišbar, Saopštenja Zavoda za zaštitu spomenika kulture Narodne Republike Srbije I: 133-135).

\section{Кузмановић-Цветковић, Ј. 1995}

Митрина икона из Џигоља, Нишки зборник 19: 165-169.

(Kuzmanović-Cvetković, J. 1995

Mitrina ikona iz Džigolja, Niški zbornik 19: 165169).

\section{Mirković, M. 1996}

The Iron gates (Đerdap) and Roman policy on the Moesian limes ad 33-117, in: The Roman limes on the Middle and Lower Danube, (ed.) P. Petrović, Beograd: Archaeological Institute, 27-40.

\section{Najdenova, V. 1989}

Mithraism in Lower Moesia and Thrace, in: Aufstieg und Niedergang der Römischen Welt, Band 18.2, (eds.) H. Temporini und W. Haase, BerlinNew York: Walter de Gruyter, 1397-1422.

\section{Петровић, В. 2007}

Дарданија у римским итинерарима. Градови и насеља, Београд: Балканолошки институт. (Petrović, V. 2007

Dardanija u rimskim itinerarima. Gradovi i naselja, Beograd: Balkanološki institut).

\section{Petrović, P. 1979}

Naissus-Remesiana-Horreum Margi, Insriptions de la Mésie Supérieure IV, Beograd: Faculté de philosophie de l'Université de Beograd.

\section{Petrović, P. 1995}

Timacum Minus et la vallée du Timok, Inscriptions de la Mésie Supérieure III/2, Beograd: Faculté de philosophie de 1〉Université de Beograd. 


\section{Пешић, Д. (ур.) 2004}

Археолошко благо Ниша од неолита до средњег века, Београд: Српска академија наука и уметности .

(Pešić, D. (ur.) 2004

Arheološko blago Niša od neolita do srednjeg veka, Beograd: Srpska akademija nauka i umetnosti).

\section{Пилиповић, С. 2011}

Култ Бахуса на Централном Балкану, I-IV век, Београд: Балканолошки институт САНУ. (Pilipović, S. 2011

Kult Bahusa na Centralnom Balkanu, I-IV vek, Beograd: Balkanološki institut SANU).

\section{Рашковић, Д. 2006}

Римско насеље Praesidium Pompei - Римљани у Алексиначкој котлини, Ниш и Византија V: 205-226.

(Rašković, D. 2006

Rimsko naselje Praesidium Pompei- Rimljani u Aleksinačkoj kotlini, Niš $i$ Vizantija V: 205-226).

\section{Рашковић, Д. 2011}

Култ бога Митре у окружју састава три Мораве

- Каталог изложбе, Крушевац: Народни музеј Крушевац.

(Rašković, D. 2011

Kult boga Mitre u okružju sastava tri Morave

- Katalog izložbe, Kruševac: Narodni muzej Kruševac).

\section{Рашковић, Д. 2013}

Прилог познавању археолошких налаза Алексиначке котлине, Караџић - Часопис за историју, етнологију, археологију и уметност 5 (Завичајни музеј Алексинац): 57-77.

(Rašković, D. 2013

Prilog poznavanju arheoloških nalaza Aleksinačke kotline, Karadžić - Časopis za istoriju, etnologiju, arheologiju $i$ umetnost 5 (Zavičajni muzej Aleksinac): 55-77).

\section{Рашковић, Д. 2017а}

Прилози познавању римских путних станица у Поморављу, Караџић - Часопис за историју, етнологију, археологију и уметност 9 (Завичајни музеј Алексинац): 59-74.

(Rašković, D. 2013

Prilozi poznavanju rimskih putnih stanica u Pomoravlju, Karadžić - Časopis za istoriju, etnologiju, arheologiju $i$ umetnost 9 (Zavičajni muzej Aleksinac): 59-74).

\section{Рашковић, Д. 2017b}

Археолошко налазиште Грабак у селу Почековини и римски локалитети у долини Западне Мораве, Зборник Народног музеја Археологија XXIII: 327-343.

(Rašković, D. 2017b

Arheološko nalazište Grabak u selu Počekovini i rimski lokaliteti u dolini Zapadne Morave, Zbornik Narodnog muzeja - Arheologija XXIII: 327-343).

\section{Танић, Д. 2016}

Средње Поморавље, Ресава и Левач - Простор, појам, војно-стратешки и општи стратешки значај кроз историју, Корени: Часопис за историографију и архивистику Х: 9-16.

(Tanić, D. 2016

Srednje Pomoravlje, Resava i Levač - Prostor, pojam, vojno-strateški i opšti strateški značaj kroz istoriju, Koreni: Časopis za istoriografiju $i$ arhivistiku X: 9-16).

\section{Tapavički-Ilić, M., Petković, S. 2017}

Figural Stone Decoration from Horreum Margi (Ćuprija), Banatica 27: 163-185.

\section{Turcan, R. 1996}

The cults of the Roman empire, Oxford: Blackwell.

\section{Ulansey, D. 1991}

The origins of the Mithraic Mysteries: Cosmology and Salvation in the Ancient World, Oxford: Oxford University Press. 
Васић, М. 1992

Нов Митрин рељеф из Horreum Margi (Ћуприја), Зборник радова Народног музеја Археологија XIV/1: 379-385.

(Vasić, M. 1992

Nov Mitrin reljef iz Horreum Margi (Ćuprija), Zbornik Narodnog muzeja - Arheologija XIV/1: 379-385).

\section{Vasić, M., Milošević, G. 2000}

Mansio Idimum. Rimska poštanska i putna stanica kod Medveđe, Beograd: Arheološki institut i Narodni muzej.

\section{Васић, М., Петковић, С. 2010}

Резултати истраживања вишеслојног налазишта Horreum Margi - Равно - Ћуприја у 1990. години, Весник војног музеја 37: 9-25. (Vasić, M. Petković, S. 2010

Rezultati istraživanja višeslojnog nalazišta Horreum Margi - Ravno - Ćuprija u 1990. godini, Vesnik vojnog muzeja 37: 9-25).

\section{Васиљевић, Љ. 2017}

Вотивни рељефни споменици из античке археолошке збирке Народног музеја Крушевац, у: Капија Поморавља у духовној историји српског народа, Својново-Крушевац: Удружење за културу и уметност Логос и Историјски архив Крушевац, 23-26.

(Vasiljević, Lj. 2017

Votivni reljefni spomenici iz antičke arheološke zbirke Narodnog muzeja Kruševac, u: Kapija Pomoravlja u duhovnoj istoriji srpskog naroda, Svojnovo-Kruševac: Udruženje za kulturu i umetnost Logos i Istorijski arhiv Kruševac, 23-26).

\section{Veljković, Ž., Vasiljević, Lj. 2020}

The Votive Inscription of HPO $\Delta \mathrm{OTO} \Sigma$ PA $\Delta \mathrm{OY}$ Found in Nozrina, Linguistique Balkanique LIX -2 (2020): 333-338.

\section{Vermaseren, M. 1960}

Corpus Inscriptionum et Monumentorum Religionis Mithriacae, Vol. 2, Hague: Martinus Nijhoff.

\section{Vetnić, S. 1967}

Ilinjača, Dragovo, Svetozarevo - Antički period, Arheološki pregled 9: 116-118.

\section{Вулић, Н. 1934}

Антички споменици наше земље, Споменик Српске Краљевске академије LXXVII: 29-84 (Vulić, N. 1934

Antički spomenici naše zemlje, Spomenik Srpske Kraljevske akademije LXXVII: 29-84).

Вълчев, И. 2015

Извънградските светилища в римската провинция Тракия, София: Университетско издателство „Св. Климент Охридски.“

(Valchev, I. 2015

Extraurban sanctuaries in the Roman province of Thrace, Sofia: St. Kliment Ohridski University Press).

\section{Зотовић, Љ. 1973}

Митраизам на тлу Југославије, Посебна издања, књ.11, Београд: Археолошки институт. (Zotović, Lj. 1973

Mitraizam na tlu Jugoslavije, Posebna izdanja, кnj. 11, Beograd: Arheološki institut).

\section{Зотовић-Жунковић, Љ., Шалабалић, Р.} 1958/1959

Нов споменик Митриног култа, Старинар (н.c.) 9/10: 205-210.

(Zotović-Žunković, Lj., Šalabalić, R. 1958/1959

Nov spomenik Mitrinog kulta, Starinar (n.s.) 9/10: 205-210). 
REZIME

PRILOG PROUČAVANJU KULTA BOGA MITRE U GORNJOJ MEZIJI: NALAZI IZ SREDNJEG I JUŽNOG POMORAVLJA

\section{KLJUČNE REČI: MITRA, TAUROKTONIJA, RIMSKI KULT, IKONOGRAFIJA, SVETILIŠTA, POMORAVLJE.}

U radu su predstavljeni nalazi Mitrinog kulta sa teritorije Južnog i Srednjeg Pomoravlja, kao područja koje je imalo izuzetan strateški značaj tokom rimske epohe, povezujući unutrašnjost Balkana sa Podunavljem. Važnost komunikacije koja se odvijala dolinom Morave naglašena je materijalnim ostacima brojnih naselja i putnih stanica, uz mnoge nalaze religiozne prirode. Tako su ovde prikazani votivni reljefi koji su zabeleženi u Ćupriji, selu Dragovu kod Rekovca i u ataru sela Džigolj kod Prokuplja, zatim selu Nozrina kod Aleksinca i okolini sela Ražanj, odnosno sa lokaliteta koji uglavnom prate magistralni put između dva veća gradska naselja rimske epohe, municipijuma Horreum Margi i perifernog područja Naissus-a.

Analizom ikonografskih i stilskih osobenosti predstavljenih nalaza, došlo se do zaključka da je reč o spomenicima mahom provincijalne izrade, koji uglavnom ne odudaraju od poznatih spomenika Mitrinog kulta sa naših prostora. Oni potvrđuju ranije izneta mišljenja istraživača da su određene ikonografske netipičnosti na njima verovatno nastale kao rezultat nedovoljnog razumevanja mitraičke doktrine, što je opet vodilo ka odsustvu kontrole pri reprodukovanju kanonizovanog obrasca ovog kulta.

Dodatno, takva atmosfera iznedrila je i jednu interesantnu religioznu praksu, koja se mogla odvijati u dva pravca. Prvi se odnosi na mogućnost da je bog Mitra ovde poštovan na otvorenom, u skrivenim svetilištima pokraj šumskih izvora, na šta nas navode podaci o kontekstu nalaza reljefa iz sela Dragovo i Džigolj. Sa druge strane, u nešto urbanijim područjima, javlja se tendencija da se ovo božanstvo poštovalo u sklopu manjih hramo- va zajedno sa drugim solarnim božanstvima poput Apolona i Tračkog konjanika odnosno vrhovnom dijadom Jupitera i Junone. O tome svedoče nalazi votivnih spomenika iz sela Nozrine, koji su pored pomenutog Mitrinog reljefa nađeni na istom lokalitetu, čineći jedan od osnova za pretpostavku da je upravo u tom mestu mogla biti smeštena rimska putna stanica mutatio Rappiana, poznata sa kasnoantičkih itinerera. Na području Pomoravlja sličan skupni nalaz votivnih spomenika zabeležen je i pod Karađorđevim brdom kod Paraćina, dok se paralela kada je u pitanju repertoar poštovanih božanstava donekle uviđa i na lokalitetu Sveta Trojica u Ravni (Timacum Minus).

$* * *$

Arheologija i prirodne nauke (Archaeology and Science) is an Open Access Journal. All articles can be downloaded free of charge and used in accordance with the licence Creative Commons - Attribution-NonCommercial-NoDerivs 3.0 Serbia (https://creativecommons.org/licenses/bync-nd/3.0/rs/.

Časopis Arheologija i prirodne nauke je dostupan u režimu otvorenog pristupa. Članci objavljeni u časopisu mogu se besplatno preuzeti sa sajta i koristiti u skladu sa licencom Creative Commons - Autorstvo-Nekomercijalno-Bez prerada 3.0 Srbija (https://creativecommons.org/licenses/bync-nd/3.0/rs/. 